\title{
The Effect of Honey on the Healing of Oral Ulcers(Clinical Study).
}

Shatha S Mohamed M Sc, D S, phD. (Prof)

Asmaa S Al-Douri

M Sc, D S, phD. (Lectu)

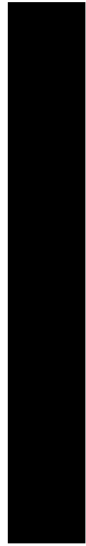

\author{
Department of Oral and Maxillofacial Surgery \\ College of Dentistry, University of Bagdad
}

Department of Oral and Maxillofacial Surgery

College of Dentistry, University of Mosul

\section{ABSTRACT}

Aim: to assess the effect of honey on healing of recurrent aphthous ulcers. Materials and Methods: fifty patients with minor oral ulcers $(2-5 \mathrm{~mm})$ were attended to consultant clinic in the College of Dentistry demanding a treatment for their painful ulcers were treated by either kenalog in orabase or the application of honey dressing. Results: The ulcerations have almost completely disappeared after 3 days treatment by honey dressing. Conclusions: Honey has an obvious influence on the rate of healing process of the oral ulcers.

Key words:Ulcers, healing, honey

Mohamed SS, Al-Douri AS. The Effect of Honey on the Healing of Oral Ulcers (Clinical Study). AlRafidain Dent J. 2008; 8(2):157-160.

Received: 24/4/2007

Sent to Referees: $24 / 4 / 2007$

Accepted for Publication:20/9/2007

\section{INTRODUCTION}

Recurrent Aphthous ulceration: (R.A.U) or recurrent A. Stomatitis is the most commom oral mucosal disease known to human beings, despite much clinical and research attention, the cause remain poorly understood, the ulcers are not preventable, and treatment is symptomatic $^{(1)}$ and affects to some degree $10-20$ $\%$ of the population ${ }^{(2)}$. R.A.U is characterized by the periodic appearance of the painful small round or oval crateriform ulceration on the mucosa of vestibule, cheeks, lips, tongue, soft palate, floor of the mouth and the pharynx with a bright red circular inflammatory zone around the ulceration with a pseudomembrane ranging from gray to yellow in color. The incidence in both sexes are almost equally affected with a slightly higher incidence in femals ${ }^{(3-5)}$. A seasonal variation in R.A.U was noted by Ship et $a l^{(6)}$. It may have primary immunologic abnormalities that result in altered immuno - regulatory balances $^{(7)}$.

Food sensitive and allergies to other substances can cause ulcers in hematological normal patients with recurrent lesions ${ }^{(8)}$. Trauma has often been cited as a precipitating factor. Also bacterial micro- organism (such as Streptococcus sangius) or viral infection suggested as being involved in the etiology of R.A.U. Psychological factors, genetic factors and nutritional deficiency may promote aphthae ${ }^{(9)}$.

Three main clinical types of aphthae can be distinguished, minor, Herpetiform and major aphthae. Minor aphthae: are the most common and typicaly consist of shallow rounded ulcers about 2-6 mm across. Herpetiform aphthae account for about $10 \%$ of cases and consist of many minute (2mm) ulcers, which may coalesce, in a field of bright erythema, and major aphthae, the most serious form, also comprise about $10 \%$ of cases $^{(2)}$.

Honey has been described in ancient and modern medicine as being effective in the healing of various infected wounds, there have been few reports of its use in the healing of burns, ulcers and open wounds ${ }^{(10-12)}$.

Subrahmanyam ${ }^{(13)}$ found that patients with honey dressed burn wounds, early subsidence of acute inflammatory changes, better control of infection and quicker wound healing was abserved while in the silver sulfadiazin treated wounds sustained inflammatory reaction was noted even on epithelialization. The honey 
treated lesions of rabbits showed less oedema, fewer polymorphnuclear, and mononuclear cell infiltration, less necrosis, better wound contraction ${ }^{(14)}$. Vardi et al ${ }^{(15)}$ concluded that honey is useful in the treatment of post surgical wounds that are infected and do not respond to conventional systemic and local antibiotic treatment. Also Aldouri found in experimental study quicker ulcer healing observed in honey treated rate than untreated ${ }^{(16)}$. Unfortunately there is a lack of reports that assess the effect of the honey on the healing of oral ulcers in human.

The Aim of this study was to assess the effect of honey on healing of recurrent aphthous ulcers.

\section{MATERIALS AND METHODS:}

Along 6 month period, 50 patients with minor oral ulcers $(2-5 \mathrm{~mm})$ were at- tended to consultant clinic in the College of Dentistry demanding a treatment for their painful ulcers. These patients ranged in age from 28- 42 years, they should not have any systemic disease. They were examined under standardized conditions for minor ulcers on the whole oral cavity.

Two groups of patients were examined:

Group (1): 25 patients (12male, 13 female) were treated by honey application (100\% purenatural honey, applied by themselves) on their ulcers three times a day for 3 days only.

Group (2): 25 patients (12 male, 13 female) were treated by kenalog in orabase (Triamcinolon acetonide $0.1 \%$ in oral paste $5 \mathrm{~g}$ ), three times a day for 3 days only.

The patients were reexamined after treatment at 2 and 3 days (Table 1).

Table (1):Sample distribution according to patient's age, gender and size of ulcer after 2,3 day treatment

\begin{tabular}{cccccc}
\hline Groups & $\begin{array}{c}\text { Age } \\
\text { Mean }\end{array}$ & Gender & $\begin{array}{c}\text { Size of ulcer(mm) } \\
\text { Mean }\end{array}$ & $\begin{array}{c}\text { 2day treat- } \\
\text { ment mean } \\
\text { ulcer } \\
\text { size(mm) }\end{array}$ & $\begin{array}{c}\text { 3day treat- } \\
\text { ment mean } \\
\text { ulcer } \\
\text { size(mm) }\end{array}$ \\
\hline Group 1 & 30.5 & $\begin{array}{c}\text { M 12 } \\
\text { F 13 }\end{array}$ & 2.9 & 1.07 & 0 \\
\hline Group 2 & 30.5 & $\begin{array}{c}\text { M 12 } \\
\text { F 13 }\end{array}$ & 2.8 & 2 & 1.8 \\
\hline
\end{tabular}

M: Male; F:female

\section{RESULTS}

Oral ulcers in the group 1 showed a marked clinical improvement after 2 days of treatment with topical application of honey 3 times daily. The ulcers showed less oedema, better ulcer contraction, improved epithelialization, relief of pain was noted. In comparison with group 2 after 2 day of treatment with kenalog in orabase ointment, there was lack of pain relief and

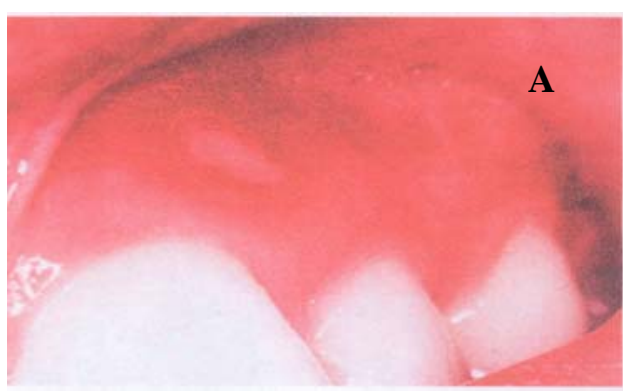

ulcers were clearly present.

After 3 days of honey treatment, the ulcers were closed, clean, and sterile, the ulcers has almost completely disappeared (Figure 1). On the other hand after 3 days of kenalog treatment, there were very slight improvement, slight relief of pain, slight contraction, slight decrease in ulcer size (Figure 2).

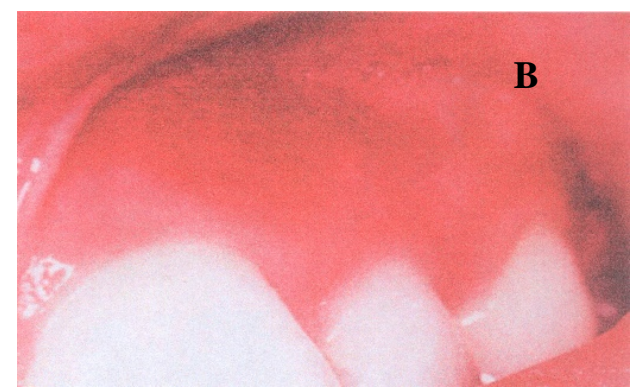

Figure (1): (a) Minor aphthous ulcer on the alveolar mucosa before treatment. (b) after 3 days of treatment with honey 

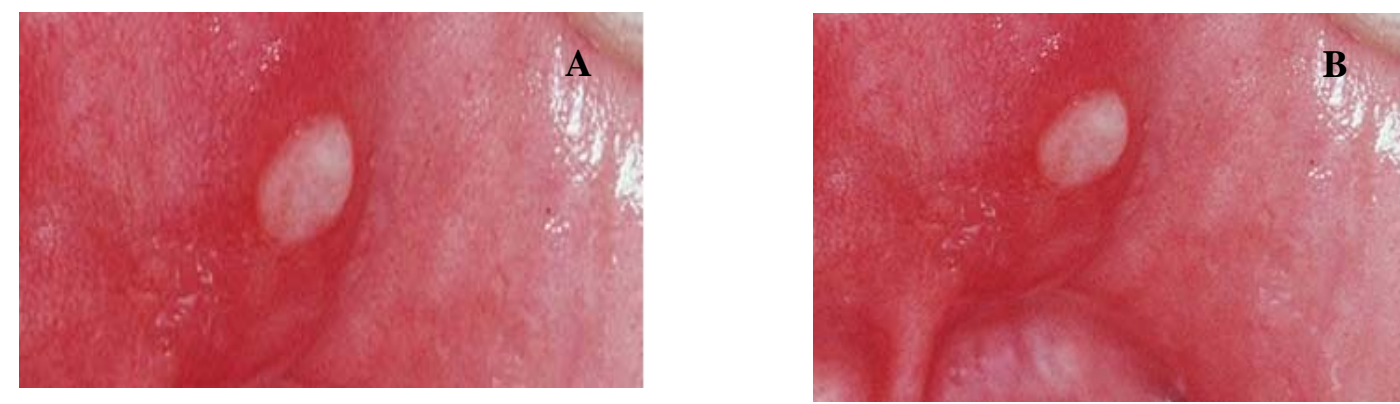

Figure (2): (a) Minor aphthous lesion on the labial mucosa before treatment; (b) After 3 days of treatment with kenalog in ora base

The difference in the effect of honey and kenaloge inorabase on the healing time was significant .The $p$-value for ho- ney treated group compared to kenaloge treated group was significant in ulcer size , pain , and healing as shown in Table 2.

Table (2): The P-value for honey treated group with kenaloge treated group

\begin{tabular}{ccc}
\hline & P-value & Significant \\
\hline Ulcer Size & 0.001 & $\mathrm{~S}^{*}$ \\
Pain & 0.002 & $\mathrm{~S}$ \\
Healing & 0.001 & $\mathrm{~S}$ \\
\hline
\end{tabular}

$* \mathrm{P}<0.05$ significant; S: Significant.

\section{DISCUSSION}

The ability of honey to accelerate the healing could be attributed to its effect against the growth of common pathogenic organisms that grow at the site of ulcers or wounds and retard the healing period. Furthermore this study showed that honey has biological activity in accelerating the rate of healing process which believed to be related to its constituents since fructose, the predominant sugar in honey, is very hygroscopic ${ }^{(10)}$. Thus, along with the antibacterial properties inhibiting the growth of bacteria such as salmonella and E. coli, it makes honey an excellent skin treatment ${ }^{(17)}$ as well as oral treatment, besides other components of vitamins and minerals $^{(17)}$.The result of present study as honey an excellent accelerator of ulcer healing and has therapeutic effect in the treatment of mucosal ulcers was in agreement with the finding of Al-Waili ${ }^{(12)}$ who concluded that topical application of crude undiluted honey could faster eradication of bacterial infection, reduce period of hospital stay, and accelerate wound healing in caesarian sections. Also quicker oral ulcer healing was observed in other studies in experimental animals ${ }^{(16)}$ as well as in skin burns $^{(13)}$. Honey accelerates the healing of ulcer through decreasing bleeding and decreasing vascular permeability ${ }^{(18)}$.

Honey is probably adsorb toxins from the mucous membrane and precipitate protein, so the pus and inflammatory exudates became adsorbed by the natural honey, thus protecting the underlying tissues and enhanced normal healing and the epithelialization $^{(15)}$.

The natural honey is sticky viscous solution, that is the way to make it adherent to the ulcer. By this mechanism for coating the ulcer and prevention of secondary infection as carob ${ }^{(19)}$. No allergic mucosal reaction or toxic effects have been reported with honey usage ${ }^{(16)}$.

\section{CONCLUSION}

Honey is useful in the treatment (acceleration healing) of oral ulcers in comparison with the use of kenalog in orabase, with lack of any side effect since its constituents have biological activity on the R.A.U.

\section{REFERENCES}

1. Jonathan A, Ship DM, Ann AM. Recurrent aphthous stomatitis. Oral Surg. Oral 
Med. Oral Pathol. Radiol. Endod. 1996; 81: 141-147.

2. Cawson RA, Binnie WH, Eveson JW. Colour Atlas of Oral Disease Clinical and Pathological Correlation's. $2^{\text {nd }}$ ed. Mosby-year book Europe Ltd. 1995; Pp:11,12.

3. Sircus W, Church R, Kelleher J. Recurrent aphthous ulcer of the mouth. $J$ Med. 1957; 26: 235-249.

4. Fahmy MS. Recurrent aphthous ulcer in amixed arab community. Oral Epidemiol. 1976; 4: 160-164.

5. Cawson RA. Essential of Dental Surgery and Pathology $4^{\text {th }}$ ed, Chruchill. Living Stone. London 1984; Pp:249-254.

6. Ship II, Morris AL, Durocher RT. Recurrent aphthous ulcer and recurrent herpes labialis in a professional school student population. Oral Surg. Oral Med. Oral Path. 1960; 13: 1191-1202.

7. Landesberg R, Fallon M, Insel R. Alterations of T- helper inducer and T- Suppressor inducer cells in patients with recurrent aphthous ulcer. Oral Surg Oral Med. Oral Pathol. 1990; 69: 205-208.

8. Nolan A, Lmey PJ, Milligon KA, Forsyth A. Recurrent aphthous ulcer. and food sensitivity. J Oral Pathol Med. 1990, 20: 473-465.

9. Scully C, Porter SR. Recurrent aphthous stomatitis: current concepts of etiology, pathogenesis and management. J Oral pathol med. 1989; 18: 21-27.

10. Sato T, Miyata G. The neutraceuticle benefit, part III: honey. Nutrition. 2000; 16(6): 468-469.

11. Salcido R, Complementary and alternative medicine in wound healing (editorial). Adv wound - care J. 1999; 12 (9):
438.

12. AL-Waili NS, Saloom KY. Effects of topical honey on post oprerative wound infection due to gram positive and gram negative bacteria following cesarean section and hysterectomies. Eur J Med Res. 1999; 26: 4(3): 126-130.

13. Subrahmanyam M. A prospective randomized clinical and histological study of superficial burn wound healing with honey and silver sulfadiazine. Burns J.1998; 24(2): 157-161.

14. Oryan A , Zaker SR. Effects of topical application of honey on cutaneous wound healing in rabbits. $J$ Zentralbl Veterinarmed A. 1998; 45 (3): 181-188.

15. Vardi A, Barzilay Z, Linder N : Local application of honey for treatment of neonatal postoperative wound infection. Acta paediatr. 1998; 87(4): 429-432.

16. Aldouri AS. The effect of the honey on the healing process of oral ulcer (experimental study). Iraqi Dent J. 2003; 33:186.

17. Elaine C. Super formual arts crafts, how to make more than 360 useful products that contain honey and bees wax. 2000. Valley Hills press. Mississipi 78.

18. Ali At, Alswayed OA, Al humayd MS. Natural honey prevents ischaemiareperfusion-induced gastric mucosal lesions and increased vascular permeability in rat. Eur. J. Gastroentrol Hepatol. 1997; 9 (11) : 1101-1107.

19. Altaie TS. The effects of the carob on the healing process of recurrent Aphthous ulceration and herpes simplex ulceration. MSc. Thesis, College of Dentistry, University of Baghdad. 1998. 